\title{
39
}

\section{Differentiation of Welfare Rights for Migrants in Western Countries from 1970 to Present}

\section{Friederike Römer}

\section{Introduction}

All Western countries have seen substantial immigrant inflows in the last six decades, though the timing and size of these inflows vary between countries. Immigration fluctuates, but apart from temporary shocks in times of economic crises, there is no evidence for a decreasing trend overall. In 2018, the foreign population in Organisation for Economic Co-operation and Development (OECD) member countries on average accounted for about 13 percent of the population (OECD 2019, 40). Migration thus leads to substantial interdependencies between states and industrialised countries continue to depend on a steady supply of immigrant labour (see e.g. Boucher and Gest 2018; Messina 2007; Massey et al. 1993). Indeed, it was with the help of immigrants that many European states rebuilt their economies after the war. Though

F. Römer $(\bowtie)$

University of Bremen, Bremen, Germany

e-mail: froemer@uni-bremen.de 
initially expected to return to their countries of origin, a considerable percentage of these workers settled, and, in later years, family migration and inflows of asylum seekers further added to the size of the immigrant population.

The growth and consolidation of welfare states since the end of World War II thus did not occur in systems that were exclusively nationally or ethnically homogenous. On the contrary, the "Golden Age" of the welfare state was also a period of mass immigration. But to what extent have immigrants ${ }^{1}$ been able to access the range of welfare benefits and services available to citizens in Western welfare states? Some authors have argued that there is an inherent tension between immigration and welfare state viability, and that restricting immigrant access to benefits is a necessary side effect of welfare states' fundamental logic of demarcating eligible insiders from outsiders (Freeman 1986; for an overview see Sainsbury $2012,1-2)$. At the same time, others have asserted that there is relatively little variation in immigrant welfare rights across countries and that most migrants eventually enjoy comprehensive welfare rights which are comparable to those of citizens (Brubaker 1989).

This chapter argues that a comparative assessment of immigrant welfare rights in fact needs to take into account differences between legal categories of immigrants, between benefit types and between direct versus indirect forms of restricting access to benefits. The first section of this chapter will discuss such a multi-dimensional conceptualisation of the term "immigrant welfare rights". The second section will outline trajectories of immigrant welfare rights using comparative data for nineteen OECD countries for the years 1980-2018. Against the backdrop of these empirical findings, some of the literature that aims to explain why immigrant welfare rights might be restricted or expanded will be enlisted, notably work on the influence of political parties, welfare regimes and international norms.

\footnotetext{
${ }^{1}$ In the context of this chapter, the term "immigrant" refers to people that do not hold the citizenship of the country that they reside in, as naturalisation ensures full access to all social and political rights. The term "foreigner" is used synonymously.
} 


\section{Conceptualising Immigrant Welfare Rights}

The extent to which welfare rights are granted to immigrants is the subject of a growing body of literature. In a pivotal contribution, T.H. Marshall famously asserted that social rights are the final component of citizenship, enabling citizens to enjoy membership of society regardless of their class (Marshall 1949). But the empirical literature emphasized early on that welfare rights have also been extended to noncitizens. This status was termed "denizenship" (Hammar 1990; see also Brubaker 1989). The term describes the fact that in most Western welfare states, immigrants with long-term residency status are granted access to many benefits on the same footing as citizens before they have political rights and/or full citizenship. Overall, there was agreement in the literature that immigrant welfare rights are relatively far reaching, and restrictions only of a temporary nature.

This assumption remained relatively uncontested until recently. However, newer studies have pointed out that to fully capture the extent to which immigrants are in- or excluded from systems of social protection, one needs to acknowledge the wide array of legal categories of entry and residence that determine immigrants' eligibility for benefits (Sainsbury 2012; Römer 2017; Koning 2019). Focusing only on the rights that are associated with permanent residency omits important variation that stems from rights granted to or withheld from other groups of migrants. This is all the more relevant in light of the fact that temporary migration is a sizeable portion of all migration flows. In 2017, 4.9 million temporary labour migrants entered OECD countries, compared to 5.2 million permanent labour migrants (OECD 2019, 20, 25). The term "immigrant welfare rights" should thus rather be understood as an umbrella term which encompasses a variety of differently restricted access rights for different groups of immigrants.

The specificities of legal categories of entry and settlement are often idiosyncratic to a given country. Broadly speaking however, most countries differentiate between six categories of migration (see Bjerre et al. 2015; Boucher and Gest 2018). These are labour, family reunification, 
asylum and refugee, "co-ethnic" and irregular (also called "illegal") migration (Bjerre et al. 2015, 559). Furthermore, virtually all countries differentiate between temporary and permanent forms of migration and residency, a differentiation that to some extent cuts across the aforementioned six categories (there are e.g. both temporary and permanent labour migrants, and of course transitions between different categories also occur). ${ }^{2}$ Lastly, regional and bilateral agreements can have important implications for immigrant welfare rights as well (Bruzelius and SeeleibKaiser 2017; Avato et al. 2010).

Just as the term "immigrant" is a collective term for several different immigrant groups, the term "welfare rights" subsumes the rights to a number of different benefits and services. Welfare states usually protect against a variety of risks such as unemployment, sickness, invalidity, disability and old age. In principle, a conceptualisation of immigrant welfare rights can thus be thought of as a continuum, taking into account both different types of benefits and different legal categories of immigrants. At the restrictive end, all immigrants would be excluded from all benefits the welfare state in a given country offers. At the other end of the spectrum, there would be no differentiation between immigrants and citizens, and any type of immigrant would be able to access all the types of welfare benefits and services offered. ${ }^{3}$

Finally, it is important to note that immigrant welfare rights can not only be curtailed directly, but also indirectly. Indirect restrictions include tying residency rights to employment, or prohibiting family reunification or attainment of citizenship for recipients of welfare benefits. Through such indirect measures, countries can thus ensure that immigrants will not be in the position to claim benefits without directly curtailing access to benefits. These kinds of restrictions thus are specific to immigrants in

\footnotetext{
${ }^{2}$ More finely grained legal categories do exist; for example, some countries operate more than one temporary labour migration scheme. Trajectories that lead to permanent residency also differ. For example, in Australia, permanent residency is granted to some labour migrants at entry, whereas in most European countries, permanent residency is only accessible through amassing a certain number of years as resident.

${ }^{3}$ Given that they fulfil eligibility requirements that are not connected to citizenship or residency status.
} 
that they rely on the defining feature of immigrant status limited residency rights-to exert control.

\section{The Development of Immigrant Welfare Rights Over Time}

It would be beyond the scope of this chapter to give an assessment of immigrants' welfare rights across all different benefit and permit types. Instead, two types of benefits that are targeted towards the able-bodied, working-age adult will be examined here, namely non-contributory social assistance benefits and contributory unemployment insurance. As argued in more detail elsewhere (Römer et al. 2021) the focus on these two types of benefits is fruitful, because it allows to draw comparisons between a type of benefit that is financed (at least to a certain extent) by contributions of the recipients themselves and a tax-funded benefit (see also Sainsbury 2012, 11-12; Brubaker 1989, 155-56). Restrictions do exist in regard to immigrant access to unemployment schemes (e.g. requirements to have contributed longer than citizens before being able to claim benefits, or non-transferability). Immigrant access to social assistance is, however, more contested because the benefit is not based on prior contributions, and therefore questions of deservingness tend to be more controversial (van Oorschot 2006).

The following descriptive assessment of immigrant welfare rights relies on a dataset that combines data collected in the projects Immigration Policies in Comparison (IMPIC) (Bjerre et al. 2015) and Migrant Social Protection (MigSP) (Römer et al. 2021). ${ }^{4}$ The data cover nineteen OECD countries and all years between 1980 and $2018 .^{5}$ Twelve items measure

\footnotetext{
${ }^{4}$ A growing number of datasets allows comparative assessments of migrants' welfare rights over time and between countries, but the combined IMPIC-MigSP measure is the only one that allows to track annual levels of rights instead of changes and/or covering only a limited number of points in time (Koning 2019).

${ }^{5}$ The full dataset also includes countries in Central and Eastern Europe as well as Latin America and South East Asia, totalling thirty-nine countries.
} 
direct and indirect restrictions of immigrant welfare rights, ${ }^{6}$ among them access to social assistance for temporary and permanent labour migrants, asylum seekers and recognised refugees, access to unemployment insurance for temporary and permanent labour migrants, type of benefit for asylum seekers, consequences of job loss and benefit receipt, and income requirements for family reunification (for a detailed list of items see Römer 2017, 180). ${ }^{7}$ Higher scores denote more rights; more specifically, a score of 1 denotes rights equivalent to those granted to citizens, whereas 0 denotes that all rights are denied. Intermediate values denote additional requirements, for example the years of required residence in the country.

Let us start with looking at the two dimensions of differentiation that previous literature has pointed to, namely contribution versus tax-based benefits, as well as residence status. Figure 39.1 shows a comparison between an index of restrictions in regard to unemployment and an index of restrictions in regard to social assistance benefits. For both indices, access to the respective benefit for both temporary and permanent migrant workers was averaged. Figure 39.1 clearly indicates that for all years 1980-2018, with only very few exceptions, access rights to social assistance are more restricted than access rights to unemployment insurance, even though some restrictions also apply to unemployment insurance benefits. This is thus in line with theoretical expectations that contribution-based benefits are less likely to differentiate between immigrants and citizens.

Figure 39.2 compares the rights of permanent migrants ${ }^{8}$ and temporary migrants, averaging the access rights and consequences each respective group faces. ${ }^{9}$ The expectation that holders of a permanent permit enjoy more access rights and face fewer consequences than temporary migrants is confirmed across all years. This is especially pronounced for recognised refugees (disaggregated measure not depicted) who enjoy

\footnotetext{
${ }^{6}$ Migration that falls under regional agreements is excluded here; see, for example, Bruzelius and Seeleib-Kaiser (2017) for an assessment of the rights of EU migrants in practice.

${ }^{7}$ The dataset does not include measures of rights of irregular migrants, who generally tend to have very limited or no access to welfare benefits and services.

${ }^{8}$ Defined as permanent labour migrants and recognised refugees.

${ }^{9}$ Defined as temporary labour migrants and asylum seekers.
} 


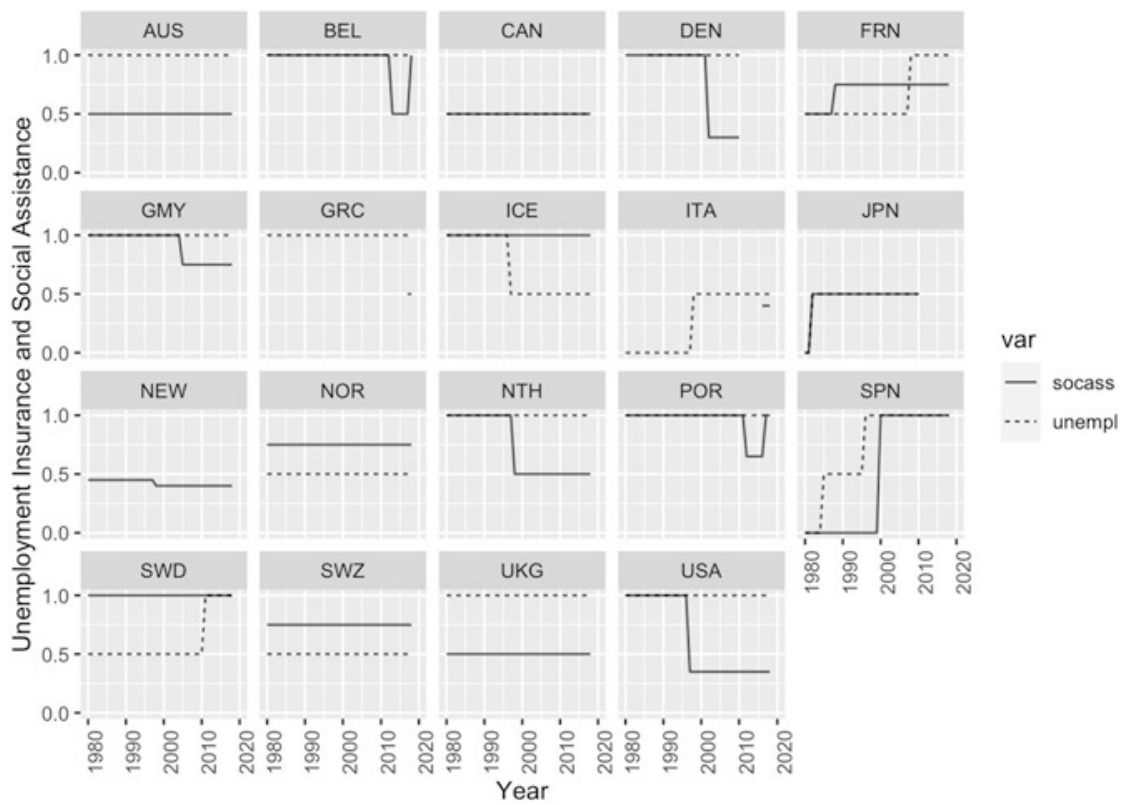

Fig. 39.1 Rights to unemployment insurance versus social assistance, 1980-2018, for nineteen OECD countries. New Zealand does not operate public unemployment insurance

welfare rights similar to those granted to citizens in almost all countries. To some extent this confirms the hypothesis of "post-national citizenship" (Soysal 1994), which claims that international human rights norms are powerfully influencing states' policies. There are however exceptions to this rule, and restrictions in rights of recognised refugees apply, for example, in Denmark and Sweden. Furthermore, human rights norms do not seem to permeate nation states' sovereignty in regard to asylum seekers, whose welfare rights tend to be among the least protected.

Figure 39.3 shows how the index of immigrant welfare rights, the unweighted average of all twelve items, has developed over time. The data show that in none of the countries in the sample, immigrant welfare rights are equivalent to those of citizens (which would be scored as 1). But the data also show that no country completely withholds rights from immigrants (which would be scored as 0 ). In regard to developments over 


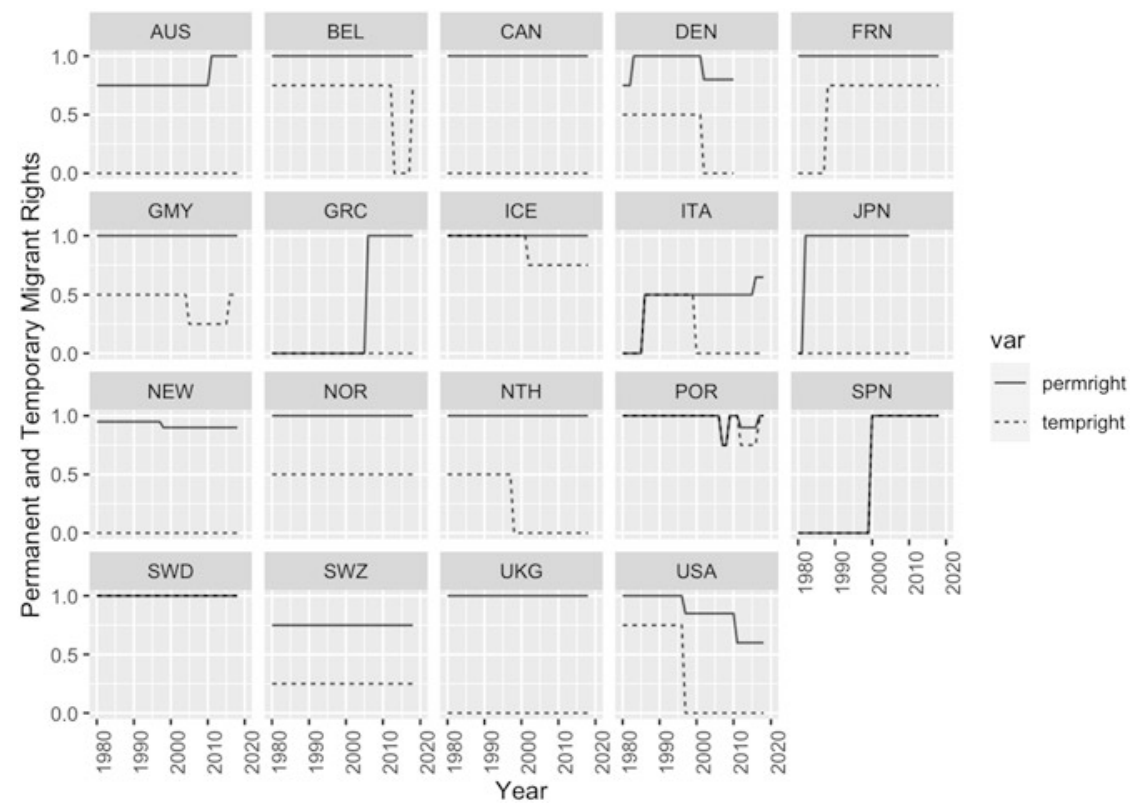

Fig. 39.2 Rights of permanent versus temporary migrants, 1980-2018, for nineteen OECD countries

time, it can be noted that a majority of countries was more generous in 1980 than they are in 2018. Interestingly, the Southern European countries differ in that they exhibit a number of liberal changes, with notable expansions in immigrant welfare rights overall. ${ }^{10}$ Especially pronounced trajectories towards restrictiveness can be observed most in Denmark, Germany, the Netherlands, and the United States, even though restrictions occur at different points in time.

This trend towards restrictiveness can be interpreted in light of the fact that even though immigrant populations did not become a central political issue in most Western European countries before the early 1990s, during the 1960s and 1970s civil society had successfully lobbied for inclusion, and in this endeavour was also backed by the courts (Joppke

\footnotetext{
${ }^{10}$ It is important to keep in mind that immigrant welfare rights are conceptualised as rights relative to citizens here-in other words, two countries scoring, for example, 0.8 does not mean that immigrants get the same amount of money in absolute terms.
} 


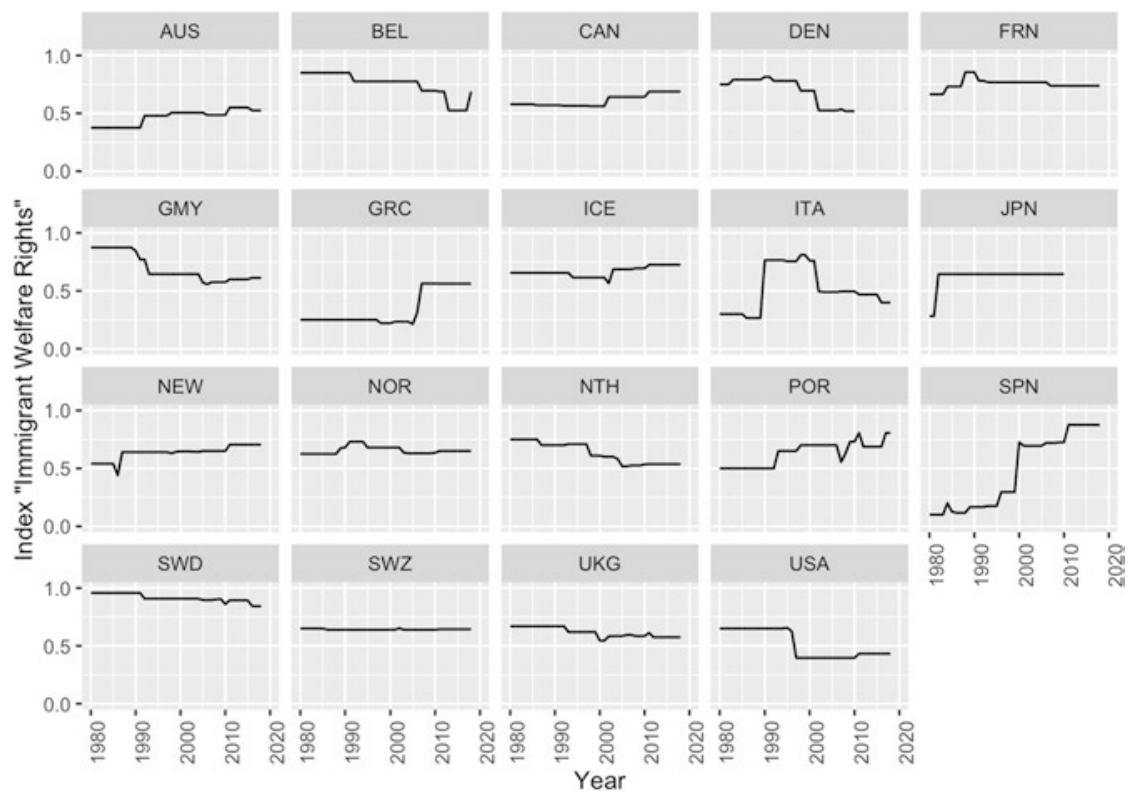

Fig. 39.3 Index of immigrant welfare rights, 1980-2018, for nineteen OECD countries

2001). However, since the early 1990s, immigration has become a focal point in the political and public debate (Messina 2007). With the rise of populist radical right-wing parties, "welfare chauvinism", in other words, the belief that welfare benefits should be reserved for the "native" population (see e.g. Kitschelt and McGann 1997, 22), gained political momentum, and ultimately also led to restrictive policy changes (Chueri 2021).

There are however differences between countries in regard to overall restrictiveness. These seem to be by and large unrelated to fiscal factors and immigration history. No cluster can be derived from sorting countries by gross domestic product (GDP) per capita, and neither within the group of settler states or the guest worker countries a clear pattern can be discerned. Solely the new immigration countries in Southern Europe seem to be similar in that they have increased immigrant rights over the last fifteen to twenty years - with the exception of Italy, whose return to restrictive policies can be explained by the influence of a right-wing party. 
The between-country differences can, at least to some extent, be attributed to welfare regime characteristics: countries that are more generous towards their citizens also grant more rights to immigrants. This is again more pronounced in 1980 than in later years though. Generous Sweden and Belgium however stand out as cases that grant relatively extensive rights over the whole period of time, with only limited changes, whereas the United States and Australia are always below average in this regard. However, the positive relationship between generosity and immigrant welfare rights found in previous studies (Römer 2017; Schmitt and Teney 2019) in part also stems from mechanisms at play within a country, for example cuts in immigrant welfare rights often occurred in the context of larger-scale retrenchment reforms.

\section{$4 \quad$ By Way of Conclusion: The Future of Immigrant Welfare Rights}

Welfare states have never been closed entities. Borders have and continue to be porous, with people entering and exiting continuously. This raises the question what welfare states do for the non-citizen part of their populations. This chapter has shown that immigrant rights vary across entry categories and benefit types, and also that there is variation both between countries and over time. The welfare regime, domestic political factors and international norms were outlined as relevant explanatory factors for these variations. Overall, it seems that there is a move towards restrictiveness, leaving immigrants across Western welfare states in a more vulnerable position than in the 1980s. It seems that even traditionally generous welfare states are not immune to shifts to the right in the political landscapes, and it remains to be seen to what extent these systems will stay true to the egalitarian creed they are based on.

The purpose of the welfare state is to provide equal opportunities "beyond and complementary to the market" (Hansen et al. 2006, 19). Today, in most countries, immigrants take on average lower socioeconomic position than non-migrants. Furthermore, short-term and circular migration are increasingly discussed as desirable forms of migration. 
Temporary permits further increase uncertainties for immigrants. Against this backdrop it seems highly relevant to investigate how welfare states protect immigrants from the risks of unemployment in increasingly flexible labour markets. Future research should be directed at how immigrants have been affected by cuts and expansion to have a clear understanding of the ways in which mature welfare states may amplify or alleviate ethnic inequalities.

Acknowledgements This chapter is a product of the research conducted in the Collaborative Research Center "Global Dynamics of Social Policy" at the University of Bremen. The centre is funded by the Deutsche Forschungsgemeinschaft (DFG, German Research Foundation)—project number 374666841-SFB 1342.

\section{References}

Avato, Johanna, Johannes Koettl, and Rachel Sabates-Wheeler. 2010. Social Security Regimes, Global Estimates, and Good Practices: The Status of Social Protection for International Migrants. World Development 38 (4): 455-466. Bjerre, Liv, Marc Helbling, Friederike Römer, and Malisa Zobel. 2015. Conceptualizing and Measuring Immigration Policies: A Comparative Perspective. International Migration Review 49 (3): 555-600.

Boucher, Anna K., and Justin Gest. 2018. Crossroads: Comparative Immigration Regimes in a World of Demographic Change. Cambridge: Cambridge University Press.

Brubaker, Rogers. 1989. Membership without Citizenship: The Economic and Social Rights of Noncitizens. In Immigration and the Politics of Citizenship in Europe and North America, ed. Rogers Brubaker, 145-162. New York: University Press of America.

Bruzelius, Cecilia, and Martin Seeleib-Kaiser. 2017. European Citizenship and Social Rights. In Handbook of European Social Policy, ed. Patricia Kennett and Noemi Lendvai-Bainton, 155-166. Cheltenham, UK: Edward Elgar Publishing.

Freeman, Gary P. 1986. Migration and the Political Economy of the Welfare State. The Annals of the American Academy of Political and Social Science 485 (1): 51-63. 
Hammar, Tomas. 1990. Democracy and the Nation State: Aliens, Denizens and Citizens in a World of International Migration. Aldershot: Ashgate Publishing. Hansen, Peo, Stephen Castles, and Carl-Ulrik Schierup. 2006. Migration, Citizenship, and the European Welfare State. A European Dilemma. Oxford: Oxford University Press.

Joppke, Christian. 2001. The Legal-Domestic Sources of Immigrant Rights: The United States, Germany, and the European Union. Comparative Political Studies 34 (4): 339-366.

Kitschelt, Herbert, and Anthony J. McGann. 1997. The Radical Right in Western Europe. A Comparative Analysis. Ann Arbor: University of Michigan Press. Koning, Edward Anthony. 2019. Immigration and the Politics of Welfare Exclusion: Selective Solidarity in Western Democracies. Toronto: University of Toronto Press.

Marshall, T.H. 1949. Citizenship and Social Class. In The Welfare State Reader, ed. Christopher Pierson and Francis G. Castles, 30-39. Cambridge: Polity.

Massey, Douglas S., Joaquin Arango, Graeme Hugo, Ali Kouaouci, Adela Pellegrino, and J. Edward Taylor. 1993. Theories of International Migration: A Review and Appraisal. Population and Development Review 19 (3): 431-466. Messina, Anthony M. 2007. The Logics and Politics of Post-WWII Migration to Western Europe. Cambridge: Cambridge University Press.

OECD. 2019. International Migration Outlook 2019. Paris: OECD Publishing. Oorschot, Wim van. 2006. Making the Difference in Social Europe: Deservingness Perceptions among Citizens of European Welfare States. Journal of European Social Policy 16 (1): 23-42.

Römer, Friederike. 2017. Generous to All or 'Insiders Only'? The Relationship between Welfare State Generosity and Immigrant Welfare Rights. Journal of European Social Policy Policy 27 (2): 173-196.

Römer, Friederike, Jakob Henninger, Eloisa Harris, and Franziska Missler (2021). Technical Report of MigSP Data. CRC 1342 Technical Paper Series 10, University of Bremen.

Sainsbury, Diane. 2012. Welfare States and Immigrant Rights: The Politics of Inclusion and Exclusion. Oxford: Oxford University Press.

Schmitt, Carina, and Céline Teney. 2019. Access to General Social Protection for Immigrants in Advanced Democracies. Journal of European Social Policy 29 (1): 44-55.

Soysal, Yasemin N. 1994. Limits of Citizenship: Migrants and Postnational Membership in Europe. Chicago: University of Chicago Press. 
Open Access This chapter is licensed under the terms of the Creative Commons Attribution 4.0 International License (http://creativecommons.org/licenses/ by/4.0/), which permits use, sharing, adaptation, distribution and reproduction in any medium or format, as long as you give appropriate credit to the original author(s) and the source, provide a link to the Creative Commons licence and indicate if changes were made.

The images or other third party material in this chapter are included in the chapter's Creative Commons licence, unless indicated otherwise in a credit line to the material. If material is not included in the chapter's Creative Commons licence and your intended use is not permitted by statutory regulation or exceeds the permitted use, you will need to obtain permission directly from the copyright holder.

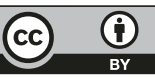

